\title{
Responses of Vitis vinifera L. cv. Sultanina to Level of Soil Water Depletion Under Semi-Arid Conditions
}

\author{
P.A. Myburgh* \\ ARC Infruitec-Nietvoorbij, Private Bag X5026, 7599 Stellenbosch, South Africa \\ Submitted for publication: October 2002 \\ Accepted for publication: April 2003 \\ Key words: Semi-arid, irrigation, soil water, water relations, Sultanina
}

\begin{abstract}
Sultanina grapevines were irrigated at $90 \%, 60 \%$ and $30 \%$ plant-available water (PAW) depletion during the growing season in a field trial on a fine sandy soil in the Lower Orange River region of South Africa. Grapevines of all treatments were irrigated at $60 \%$ PAW depletion during winter. Measurement of diurnal leaf water potential $\left(\Psi_{1}\right)$ cycles at different stages during the season showed that plant water status was not only a function of soil water availability, but also of meteorological conditions. Increasing vapour pressure deficit (VPD) decreased pre-dawn leaf water potential, suggesting nocturnal water loss via transpiration. On the other hand, $\Psi_{1}$ measured at $14 \mathrm{~h} 00$ increased with an increase in VPD, indicating partial stomatal closure during the warmest part of the day. Vegetative growth, berry mass and production increased with increased plant water status as imposed by the different PAW depletion levels. PAW depletion level had almost no effect on sugar accumulation or acid breakdown. Soil water depletion level had no effect on the quality of dipped raisins. Hence, the ideal balance between vegetative growth, yield and water use efficiency for the production of dipped Sultanina raisins was obtained with irrigation at $60 \%$ PAW depletion. Since quality of sun-dried raisins was considerably reduced by irrigation at $60 \%$ as well as 90\% PAW depletion, relative to $30 \%$ depletion, the latter seems to be the optimum depletion level for sun-dried raisin production. This optimum depletion level might not be applicable for irrigation of Sultanina on heavier, more fertile alluvial soils.
\end{abstract}

The majority of South Africa's Sultanina (Sultana or Thompson's Seedless) raisins are produced along the Lower Orange River in the summer rainfall region. Traditionally vineyards were established on alluvial soils, but are currently expanding onto more sandy or gravelly soils further away from the river. Since mean summer rainfall in this semi-arid region is insufficient to sustain viticulture, irrigation is essential. Raisin-grape growers aim to maximise production per unit land and, consequently, tend to apply water abundantly to avoid yield losses which could result from water stress.

Only limited guidelines for managing irrigation to obtain optimum balance between vegetative growth, yield, quality and water use are available for production of dried grapes in the warm summer rainfall regions of South Africa. Vegetative growth of grapevines increases with water application rate (Van Zyl, 1984a; Myburgh, 1996). This also applies to Sultanina (Araujo et al., 1995). Increased growth vigour (Buttrose, 1974; Myburgh et al., 1996) or leaf area per grapevine (Eastham \& Gray, 1998; Myburgh, 1998) increases grapevine water consumption. However, the increased vegetative growth which results when the availability of water is increased does not necessarily result in higher yields being obtained (Conradie et al., 1996; Conradie \& Myburgh, 2000). Untimely irrigation, in particular during ripening, will also increase the risk of disease infection, such as Botrytis cinerea (Van Zyl, 1984a). More dense canopies will increase the risk of disease infection due to lower evaporative potential in the fruit zone (English et al., 1990). Hence, when irrigation induces excessive growth without increased yield, or even reduces yield (Carbonneau \& Casteran, 1979), grapevine water-use efficiency in terms of irrigation applied per unit fruit produced will be reduced.

Water stress reduces berry size (Hardie \& Considine, 1976; Van Zyl, 1984a; Myburgh, 1996; McCarthy, 1997). This will not only reduce yield, but small berries could also have a negative effect on raisin quality. Inducing two water-deficit levels by withholding irrigation for $c a$ ten weeks or five weeks before harvest, respectively, had inconsistent effects on the quality grading of sun-dried Sultanina raisins (Christensen, 1975). However, fresh berry mass and raisin size tended to be larger when irrigation was terminated $\mathrm{ca}$ five weeks before harvest. Darkening of dipped raisins, which reduced marketing grade, occurred when Sultanina grapevines were subjected to water stress (Nagarajah, 1992). Sugar accumulation, which is crucial for quality-raisin production, can be delayed by severe water stress, resulting in leaf senescence, but may be increased when mild water stress reduces vegetative growth (Smart \& Coombe, 1983).

Leaf water potential is generally accepted as a reliable indicator of plant water status. Under normal conditions leaf water potential is greatest during the pre-dawn period. After sunrise it decreases rapidly to a minimum around $12: 00$ to $14: 00$. This is followed by a rapid increase until sunset, whereafter it increases slowly until a new pre-dawn maximum. Leaf water potential val-

*E-mail address: philipm@infruit.agric.za

Acknowledgements: Partial funding by Dried Fruit Technical Services as well as technical assistance of the Soil Science staff at ARC Infruitec-Nietvoorbij and C. Jackson of the SADOR farm. 
ues of $-0.5 \mathrm{MPa}$ during the pre-dawn period and minimum values of $-0.9 \mathrm{MPa}$ to $-1.2 \mathrm{MPa}$ during the day can be regarded as the onset of negative effects of water stress on grapevine physiology (Williams et al., 1994 and references therein). Grapevine leaf water potential is normally well related to soil water matric potential (Van Zyl, 1987) or soil water content (Williams et al., 1994). Under South African conditions the onset of water stress in Colombar grapevines occurred at a soil matric potential of $-0.064 \mathrm{MPa}$ (Van Zyl, 1987), which compares well with -0.065 MPa obtained for container-grown White Riesling grapevines (Schultz \& Matthews, 1988). Based on the relationship between plant and soil water potential, measurement of pre-dawn leaf water potential or particularly stem water potential, is considered a useful means to determine the effect of soil water content on grapevine water status (Choné et al., 2001; Van Leeuwen et al., 2001).

The aim of this study was to determine the effect of soil water depletion during summer on water status, growth, production, raisin quality and water use of Sultanina in the Lower Orange River region.

\section{MATERIALS AND METHODS}

\section{Experiment vineyard}

The field trial was carried out in a twelve-year-old, ungrafted Sultanina (Clone H4) vineyard on the SADOR farm of the South African Dried Fruit Co-operative near Upington. This locality is in a class V climatic region (Winkler, 1962) at $28^{\circ} 27^{\prime}$ South latitude. The soil, which belongs to the Plooysburg form (Soil Classification Work Group, 1991), consisted of $600 \mathrm{~mm}$ to 900 mm deep red sand on undulating, nodular, cemented limestone (Aridisol, USDA soil classification). Before planting, the soil was deep ripped to a depth of $800 \mathrm{~mm}$. Grapevines were planted 3.0 $\mathrm{m} \times 2.0 \mathrm{~m}$, trained onto a gable trellis (Zeeman, 1981) and cane pruned, allowing 12 to 18 nodes per cane. Twelve canes were allowed per grapevine. No canopy management was performed during summer, which is the norm for dried-grape vineyards in this particular region. The vineyard was irrigated by means of 32 $\mathrm{L} / \mathrm{h}$ micro-sprinklers. Irrigation quantities were measured by means of water meters on all plots.

\section{Experiment layout}

Grapevines were irrigated throughout the growing season (September to May) at 90\% (T1), 60\% (T2) and 30\% (T3) plantavailable water (PAW) depletion, respectively. All treatments were irrigated at $60 \%$ PAW depletion during winter. Treatments were replicated three times in a randomised block design and were applied from the 1995/96 season until 1998/99. Each $216 \mathrm{~m}^{2}$ plot contained twelve experiment vines with two buffer vines at each end and a buffer row on each side. These treatments were part of a field trial where the effects of water deficits during various pre-harvest phenological phases as well as the post-harvest period were investigated (Myburgh, 2003).

\section{Soil parameters}

Particle size distribution was determined on representative soil samples. Soil bulk density was determined using $28 \times 10^{-5} \mathrm{~m}^{3}$ undisturbed samples over 0-300 mm, 300-600 mm and, where possible, over $600-900 \mathrm{~mm}$ depth increments. Soil water characteristic curves of $6.8 \times 10^{-5} \mathrm{~m}^{3}$ undisturbed soil cores, sampled over the same depth increments as bulk density, were determined by means of the pressure chamber method (Klute, 1986). Samples were obtained from four soil pits that represented soil variation in the experiment vineyard. Plant-available water was calculated as the difference in soil water content between $-0.01 \mathrm{MPa}$ and -1.50 $\mathrm{MPa}$. Soil water matric potential $\left(\Psi_{\mathrm{m}}\right)$ was measured once a week as well as before and after irrigations by means of tensiometers. These were installed on the vine row ca $500 \mathrm{~mm}$ from a grapevine at $300 \mathrm{~mm}, 600 \mathrm{~mm}$ and $900 \mathrm{~mm}$ depths on all plots. Soil water matric potential was converted to soil water content by means of the soil water characteristic curves.

\section{Meteorological parameters}

Air temperature, relative humidity, wind speed, net radiation and precipitation were recorded hourly by means of an automatic weather station (MC Systems, Cape Town) erected next to the experiment vineyard. Vapour pressure deficit of the atmosphere was calculated according to Allen et al. (1998). Hourly reference crop evapotranspiration $\left(\mathrm{ET}_{\mathrm{o}}\right)$ was calculated using a modified Penman-Monteith equation (Allen et al., 1994). Hourly $\mathrm{ET}_{\mathrm{o}}$ values were summed to obtain daily $\mathrm{ET}_{\mathrm{o}}$.

\section{Evapotranspiration}

The following universal water balance equation was used to calculate evapotranspiration:

$\mathrm{ET}+\mathrm{SWC}_{\mathrm{b}}+\mathrm{I}+\mathrm{P}-\mathrm{SWC}_{\mathrm{e}}-\mathrm{D}-\mathrm{R}=0$

where ET is evapotranspiration over a given period (normally a week), $\mathrm{SWC}_{\mathrm{b}}$ and $\mathrm{SWC}_{\mathrm{e}}$ are soil water content at the beginning and end of the period, respectively, I is irrigation water applied, $\mathrm{P}$ is precipitation, $\mathrm{D}$ is drainage and $\mathrm{R}$ is run-off loss. All units were in millimeters. Due to the sandy nature of the soil, no runoff from the surface occurred and, since irrigation was applied according to soil water deficits at a particular time, drainage was assumed to be negligible. Because of instrumentation problems, ET was determined only during the first three seasons on all replications of treatments where grapevines were irrigated at $30 \%$ and 60\% PAW depletion (T3 \& T2). Crop coefficients $\left(\mathrm{k}_{\mathrm{c}}\right)$ were calculated as follows:

$\mathrm{k}_{\mathrm{c}}=\mathrm{ET} / \mathrm{ET}_{\mathrm{o}}$

\section{Plant parameters}

Vegetative growth was quantified by measuring cane mass at pruning (end July). Berry development was determined from approximately 21 days after flowering until harvest on all replications. One hundred berries were sampled at $c a$ 14-day intervals by picking five berries from each of twenty bunches per plot. Berries were picked at different positions along the longitudinal bunch axis. Grapes were harvested at a total soluble solid content of $c a 22^{\circ} \mathrm{B}$. Yield was obtained by measuring total grape mass per plot at harvest (end January). After determining berry mass at harvest, samples from all replications were macerated using a mortar and pestle and squeezed through cheesecloth to obtain juice samples. Total soluble solids, total titratable acidity and $\mathrm{pH}$ of the juice were determined by means of standard Nietvoorbij laboratory procedures. Juice was not analysed during the 1998/99 season.

To quantify plant water status, diurnal variation in leaf water potential $\left(\Psi_{1}\right)$ was measured at flowering (October), mid-season (December), during ripening (January) and late season (May) by means of the pressure chamber technique (Scholander et al., 
1965). Leaf water potential was measured at two-hour intervals from 04:00 until 20:00 in all plots. Determinations were carried out on uncovered, mature leaves which were fully exposed to sunlight (when applicable). Although it would have been preferable, it was not always possible to measure $\Psi_{1}$ cycles on days before irrigation of all treatments coincided.

\section{Raisin quality}

Quality of sun-dried as well as dipped raisins was determined for all replications of the three treatments. In the case of sun-dried raisins, ca $20 \mathrm{~kg}$ fresh grapes were spread onto $1.8 \mathrm{~m} \mathrm{x} 0.9 \mathrm{~m}$ wooden trays and dried in direct sunlight. Dipped raisins were obtained by treating fresh grape samples ( $\mathrm{ca} 20 \mathrm{~kg}$ ) in picking boxes with a solution of $\mathrm{K}_{2} \mathrm{CO}_{3}(2.5 \mathrm{~kg} / 100 \mathrm{~L})$ and fruit drying oil $(2.0 \mathrm{~L} / 100 \mathrm{~L})$ using a commercial plant on the SADOR farm. The drying oil consisted of $596 \mathrm{~g} / \mathrm{L}$ ethyl and methyl esters of fatty acids from food grade canola oil. These grapes were dried in the shade on covered wire racks similar to those generally used by growers. Depending on meteorological conditions, drying time varied between ten and fourteen days. Raisin quality was determined on $500 \mathrm{~g}$ samples by means of the commercial air-stream grading system at the South African Dried Fruit Cooperative factory at Upington. Raisin samples were separated into four classes, i.e. choice, standard, sub-standard and "of no value". Each class was expressed as a percentage of the total sample mass. Raisin quality was not determined during the 1998/99 season.

\section{Statistical analysis}

The data were subjected to an analysis of variance. Tukey's least significant difference (LSD) was calculated to facilitate comparison between treatment means. Means which differed at $p \leq 0.05$ were considered to be significantly different. Statgraphics ${ }^{\circledR}$ was used to determine relationships between parameters by means of linear regression.

\section{RESULTS AND DISCUSSION}

\section{Soil parameters and irrigation}

The soil contained $3.2 \%$ clay, $8.8 \%$ silt, $64.4 \%$ fine sand, $10.0 \%$ medium sand and $13.7 \%$ coarse sand. According to this particle size distribution, soil texture was classified as fine sand. Mean soil bulk density was $1600 \mathrm{~kg} / \mathrm{m}^{3}$. Visual observation in the soil pits showed that roots were distributed over a depth of $800 \mathrm{~mm}$. Soil water content at $-0.01 \mathrm{MPa}$ and $-1.5 \mathrm{MPa}$ was $9 \%$ and $3.5 \%$, respectively. Total plant-available water amounted to $72 \mathrm{~mm} / \mathrm{m}$. Hence, PAW was ca $58 \mathrm{~mm}$ per $800 \mathrm{~mm}$ root depth. Soil water depletion levels of $30 \%, 60 \%$ and $90 \%$ corresponded with soil water matric potentials of $-0.015 \mathrm{MPa},-0.03 \mathrm{MPa}$ and -0.07 $\mathrm{MPa}$, respectively. The respective treatments were irrigated when mean $\Psi_{\mathrm{m}}$ at $300 \mathrm{~mm}$ and $600 \mathrm{~mm}$ depths reached these values. During the peak consumption period, i.e. December and January, $\mathrm{T} 1 \mathrm{had}$ to be irrigated every three to four weeks, $\mathrm{T} 2$ every five to seven days, and T3 every three to four days to maintain the desired soil water-depletion levels. Mean volumes of irrigation water applied over the three seasons from budbreak until harvest amounted to $655 \mathrm{~mm}, 915 \mathrm{~mm}$ and $1348 \mathrm{~mm}$ for T1, T2 and T3, respectively.

Mean daily water consumption and crop coefficients of grapevines irrigated at $30 \%$ and $60 \%$ PAW depletion are presented in Table 1. These results showed that summer rainfall (Table 2)

\section{TABLE 1}

Mean Penman-Monteith reference evapotranspiration $\left(\mathrm{ET}_{\mathrm{o}}\right)$, vineyard evapotranspiration (ET) and crop coefficients $\left(\mathrm{k}_{\mathrm{c}}\right)$ for Sultanina irrigated at $30 \%$ and $60 \%$ plant available water depletion as determined over three seasons at Upington.

\begin{tabular}{|c|c|c|c|c|c|}
\hline \multirow[t]{2}{*}{ Month } & \multirow{2}{*}{$\begin{array}{c}\mathrm{ET}_{\mathrm{o}} \\
(\mathrm{mm} / \mathrm{day})\end{array}$} & \multicolumn{2}{|c|}{ ET $(\mathbf{m m} / \mathbf{d})$} & \multicolumn{2}{|c|}{$\mathbf{k}_{\mathrm{c}}$} \\
\hline & & $30 \%$ & $60 \%$ & $30 \%$ & $60 \%$ \\
\hline August & 4.98 & 1.25 & 1.25 & 0.25 & 0.25 \\
\hline September & 5.40 & 2.70 & 1.84 & 0.50 & 0.34 \\
\hline October & 6.58 & 4.26 & 2.90 & 0.65 & 0.44 \\
\hline November & 7.16 & 5.57 & 3.79 & 0.78 & 0.53 \\
\hline December & 8.52 & 8.64 & 5.88 & 1.00 & 0.69 \\
\hline January & 8.11 & 7.98 & 5.43 & 0.98 & 0.67 \\
\hline February & 7.67 & 6.76 & 4.60 & 0.88 & 0.60 \\
\hline March & 5.70 & 3.85 & 2.62 & 0.68 & 0.46 \\
\hline April & 5.18 & 2.12 & 2.12 & 0.41 & 0.41 \\
\hline May & 3.33 & 1.10 & 1.10 & 0.33 & 0.33 \\
\hline June & 3.12 & 0.66 & 0.66 & 0.21 & 0.21 \\
\hline July & 2.81 & 0.45 & 0.45 & 0.16 & 0.16 \\
\hline
\end{tabular}

would only supply a small fraction of the actual water requirements. Vineyard evapotranspiration decreases with increased soil water depletion and vice versa (Van Zyl, 1984a; Williams et al., 1994; Stevens \& Harvey, 1996). Hence, crop coefficients for grapevines irrigated at $c a 60 \%$ PAW depletion were substantially lower where $47 \%$ more water was applied to maintain 30\% PAW depletion. Furthermore, it should be noted that these crop coefficients only apply to micro-sprinkler irrigated vineyards. Due to a smaller wstted area, evapotranspiration and crop coefficients for drip-irrigated vineyards are generally lower than for micro-sprinklers (Van Zyl, 1984a; Saayman \& Lambrechts, 1995).

\section{Plant water status}

Diurnal $\Psi_{1}$ cycle values at flowering (October) remained above $-0.9 \mathrm{MPa}$ for all treatments, except during the afternoon between 14:00 and 16:00 (Fig. 1A). Although air temperatures (Fig. 1B) were comparable to the long-term means (Table 2), overcast conditions probably suppressed development of higher water stress in grapevines of the drier treatments. Overcast conditions induced a similar effect on $\Psi_{1}$ of Riesling and Sylvaner grapevines (Düring \& Loveys, 1982). On this particular day $\Psi_{\mathrm{m}}$ for T1, T2 and T3 amounted to $-0.051 \mathrm{MPa},-0.007 \mathrm{MPa}$ and $-0.006 \mathrm{MPa}$, respectively. With the exception of 16:00, these soil water depletion levels did not result in significant $\Psi_{1}$ differences under the specific conditions. Diurnal $\Psi_{1}$ values for T2 and T3 grapevines which were subjected to comparable $\Psi_{\mathrm{m}}$ indicated that their water stress tended to be lower throughout the day in comparison to that of T1 grapevines.

Pre-dawn leaf water potentials $\left(\Psi_{\mathrm{pd}}\right)$ in all treatments were below $-0.5 \mathrm{MPa}$ when the mid-season cycle was measured in December (Fig. 2A). This indicated that grapevines were subjected to relatively high water stress (Williams et al., 1994; Greenspan et al., 1996; Choné et al., 2001). During the pre-dawn period of this particular cycle vapour pressure deficit (VPD) exceeded $1 \mathrm{kPa}$ (Fig. 2B) and night temperatures were notably higher compared to the long-term mean minimum temperature values (Table 2). Against expectations, $\Psi_{1}$ of T2 and T3 remained relatively high when high temperatures and VPD prevailed throughout the day. However, leaf water potential can also be 
TABLE 2

Long-term mean temperature, relative humidity, rain and net radiation at the Upington Experiment Station (data obtained from ARC Institute for Soil, Climate and Water, Pretoria).

\begin{tabular}{|c|c|c|c|c|c|c|}
\hline \multirow[t]{2}{*}{ Month } & \multirow[t]{2}{*}{$\begin{array}{l}\text { Rain } \\
(\mathbf{m m})\end{array}$} & \multicolumn{2}{|c|}{$\begin{array}{c}\text { Temperature } \\
\left({ }^{\circ} \mathrm{C}\right)\end{array}$} & \multicolumn{2}{|c|}{$\begin{array}{l}\text { Relative humidity } \\
\qquad(\%)\end{array}$} & \multirow[t]{2}{*}{$\begin{array}{c}\text { Radiation } \\
\left(\mathrm{MJ} / \mathrm{m}^{2} / \text { day }\right)\end{array}$} \\
\hline & & maximum & minimum & maximum & minimum & \\
\hline January & 21.4 & 34.6 & 17.2 & 67.1 & 24.3 & 30.4 \\
\hline February & 26.8 & 33.6 & 17.2 & 74.9 & 26.7 & 28.3 \\
\hline March & 34.1 & 31.5 & 15.3 & 81.7 & 27.4 & 21.8 \\
\hline April & 18.7 & 27.6 & 10.6 & 86.4 & 27.5 & 18.5 \\
\hline May & 9.4 & 23.7 & 5.7 & 87.5 & 27.3 & 15.3 \\
\hline June & 2.7 & 20.6 & 2.6 & 86.6 & 28.9 & 13.9 \\
\hline July & 2.4 & 20.7 & 1.7 & 82.6 & 26.7 & 14.6 \\
\hline August & 3.5 & 22.8 & 3.5 & 79.2 & 25.7 & 18.6 \\
\hline September & 2.6 & 26.4 & 7.1 & 75.9 & 24.7 & 22.0 \\
\hline October & 8.3 & 29.0 & 10.4 & 73.3 & 24.8 & 27.1 \\
\hline November & 11.8 & 31.9 & 13.7 & 68.4 & 23.8 & 29.4 \\
\hline December & 12.9 & 33.6 & 16.1 & 66.3 & 24.5 & 30.5 \\
\hline
\end{tabular}
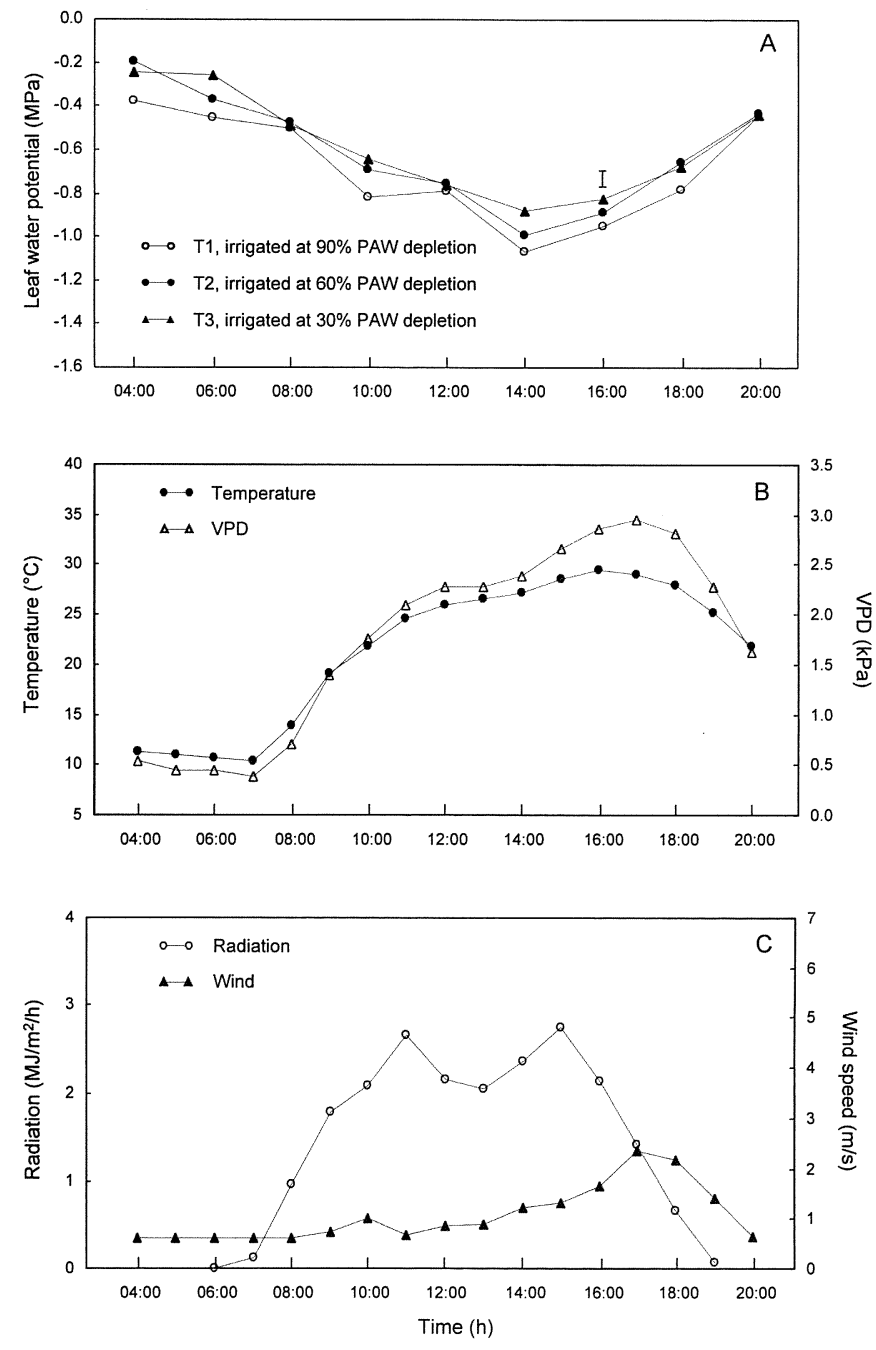

FIGURE 1

Effect of soil water depletion on (A) leaf water potential of Sultanina in relation to (B) temperature and vapour pressure deficit (VPD) as well as (C) radiation and wind speed as measured on 9 October 1995 at Upington. Vertical bar indicates significant difference $(p \leq 0.05)$. influenced by other parameters such as wind, radiation and available soil water. According to Kobriger et al. (1984), wind speed in excess of $3.0 \mathrm{~m} / \mathrm{s}$ significantly reduced grapevine transpiration, but only tended to decrease leaf water potential. This suggests that, although similar wind speeds occurred from 07:00 until 20:00 (Fig. 2C), the relatively high $\Psi_{1}$ of $\mathrm{T} 2$ and T3 during the day was probably caused by partial stomatal closure induced by overcast conditions (Düring \& Loveys, 1982) and not by the relatively high wind speeds. However, in the case of T1 grapevines, $\Psi_{1}$ dropped below $-1.2 \mathrm{MPa}$, indicating that dry soil conditions $(-0.061 \mathrm{MPa})$ caused an increase in water stress as opposed to T2 and T3, where $\Psi_{\mathrm{m}}$ was $-0.043 \mathrm{MPa}$ and $-0.016 \mathrm{MPa}$, respectively. In fact, grapevines irrigated at $90 \%$ PAW depletion experienced significantly more water stress throughout the diurnal cycle compared to T2 and T3. These results indicate that the effect of soil water content is reflected in grapevine water status irrespective of the adverse meteorological conditions. In agreement with this, Düring (1976) showed that low air humidity increased stomatal resistance of grapevines subjected to water deficits, whereas stomata of well-watered grapevines remained open. It is important to note that data obtained during this particular diurnal cycle showed that low $\Psi_{\mathrm{pd}}$ does not necessarily mean that grapevines will experience a high degree of water stress during the day.

When measured during ripening (January), $\Psi_{\mathrm{pd}}$ for all treatments was higher than $-0.5 \mathrm{MPa}$, which indicated that the grapevines were not subjected to water stress at that stage. During the day $\Psi_{1}$ decreased to values between $-1.0 \mathrm{MPa}$ and $-1.4 \mathrm{MPa}$ followed by a rapid increase after 18:00 (Fig. 3A). Although afternoon air temperatures exceeded $30^{\circ} \mathrm{C}$, which is considered normal for January (Table 2), VPD remained relatively low throughout the day (Fig. 3B). These conditions, as well as relatively high $\Psi_{\mathrm{m}}$, i.e. $-0.043 \mathrm{MPa},-0.023 \mathrm{MPa}$ and $-0.018 \mathrm{MPa}$, for T1, T2 and T3, respectively, probably prevented the development of more water stress under normal sunshine conditions (Fig. 3C). As a result, leaf water potential for $\mathrm{T} 1$ grapevines was significantly lower than that of T3 only at 04:00 and 20:00. During the rest of the day $\Psi_{1}$ of T1 and $\mathrm{T} 2$ tended to be lower compared to T3. 
In comparison to grapevines that were irrigated at $90 \%$ PAW depletion, irrigation at $60 \%$ and $30 \%$ depletion decreased water stress of grapevines during the post-harvest period (beginning of May) (Fig. 4). Although $\Psi_{\text {pd }}$ did not indicate severe water stress in grapevines of $\mathrm{T} 1$ and $\mathrm{T} 2$, values lower than $-1.2 \mathrm{MPa}$ were recorded during the day. This indicated that soil matric potentials of $-0.062 \mathrm{MPa}$ and $-0.031 \mathrm{MPa}$ for $\mathrm{T} 1$ and $\mathrm{T} 2$, respectively, induced significantly more water stress compared to $-0.009 \mathrm{MPa}$ in the case of T3 grapevines. Grapevine water status was also related to soil water content under relatively mild temperature and radiation conditions in autumn (Fig. 4B \& 4C), which is typical for the Lower Orange River region (Table 2).

Results of the four individual diurnal leaf water potential cycles showed that, irrespective of the stage of season, soil water depletion level had a consistent effect on grapevine water status on a particular day. Despite varying meteorological conditions, minimum $\Psi_{1}$ of grapevines irrigated at $30 \%$ PAW depletion tended to remain above $-1.2 \mathrm{MPa}$ throughout the season, indicating that grapevines of this particular treatment were not readily subjected to water stress. Since the onset of water stress in grapevines only
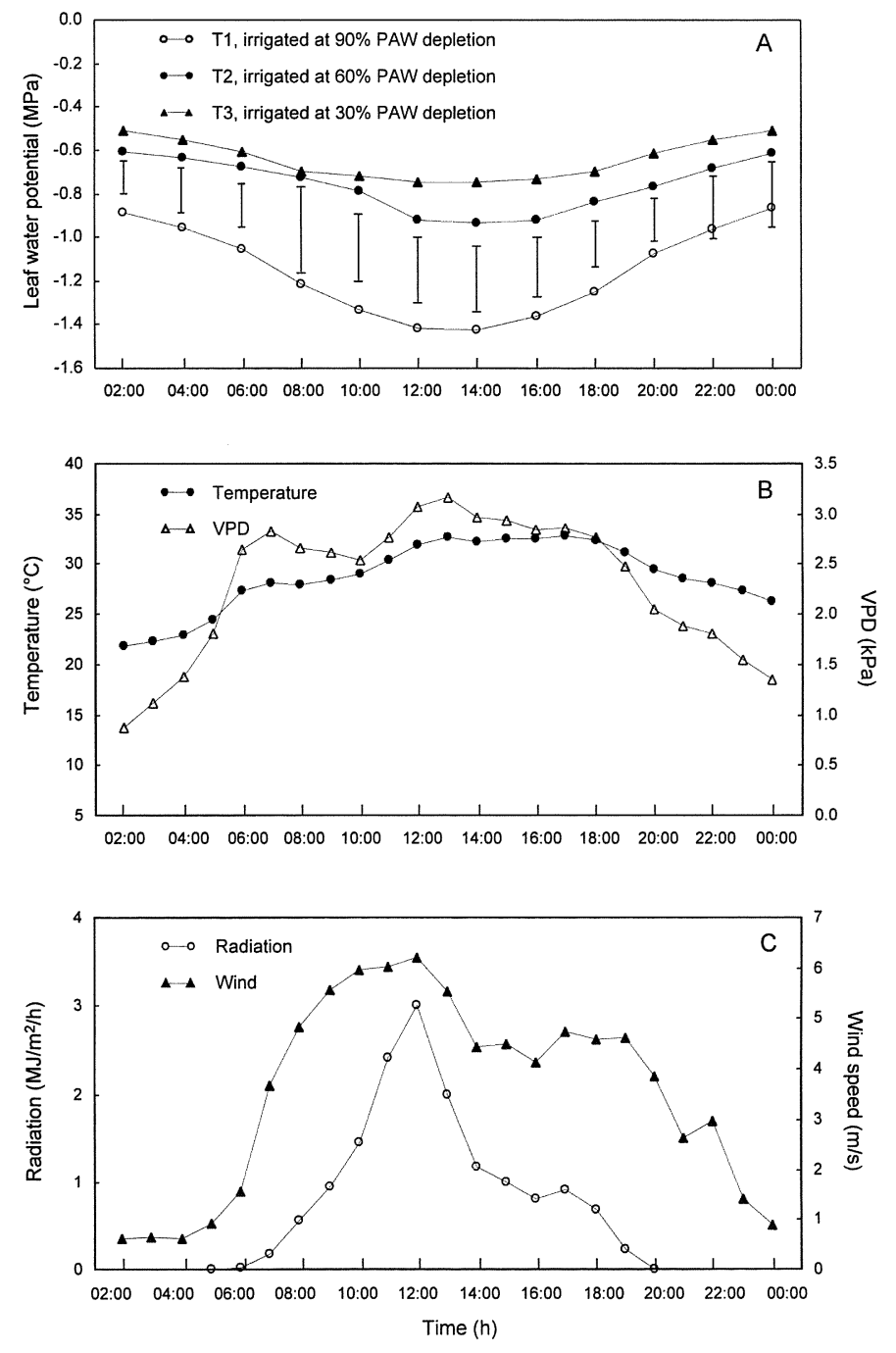

FIGURE 2

Effect of soil water depletion on (A) leaf water potential of Sultanina in relation to (B) temperature and vapour pressure deficit (VPD) as well as (C) radiation and wind speed as measured on 30 December 1997 at Upington. Vertical bars indicate significant differences $(p \leq 0.05)$ occurs at an $\Psi_{\mathrm{m}}$ of $c a-0.064 \mathrm{MPa}$ (Van Zyl, 1987; Schultz \& Matthews, 1988), the relatively high $\Psi_{\mathrm{m}}$ maintained in the case of $\mathrm{T} 1$ and $\mathrm{T} 2$ prevented the development of exceptionally low $\Psi_{1}$ in the present study.

Contrary to the findings of Van Zyl (1987) and Williams et al. (1994), $\Psi_{\mathrm{pd}}$ did not correlate particularly well with $\Psi_{\mathrm{m}}$ when data from the four diurnal cycles in the present study were combined (Table 3). This poor correlation was primarily due to the relatively low values when measurements were made during the warm, dry conditions during the night in December 1996 (Fig. 2). Hence, when $\Psi_{\mathrm{pd}}$ was related to $\Psi_{\mathrm{m}}$ as well as VPD by means of multiple linear regression, $89 \%$ of the variation in $\Psi_{\mathrm{pd}}$ could be explained (Table 3). In contrast to conditions during the day, $\Psi_{\mathrm{pd}}$ decreased with increasing VPD. Green et al. (1989) also found that increased nocturnal transpiration of kiwi fruit vines was caused by increased VPD. The foregoing findings suggest that the relatively high VPD caused water loss from the grapevines via transpiration, which significantly decreased $\Psi_{\text {pd }}$ despite relatively high $\Psi_{\mathrm{m}}$ values. At this stage it is uncertain if limits exist for the linear response of $\Psi_{\mathrm{pd}}$ to VPD.
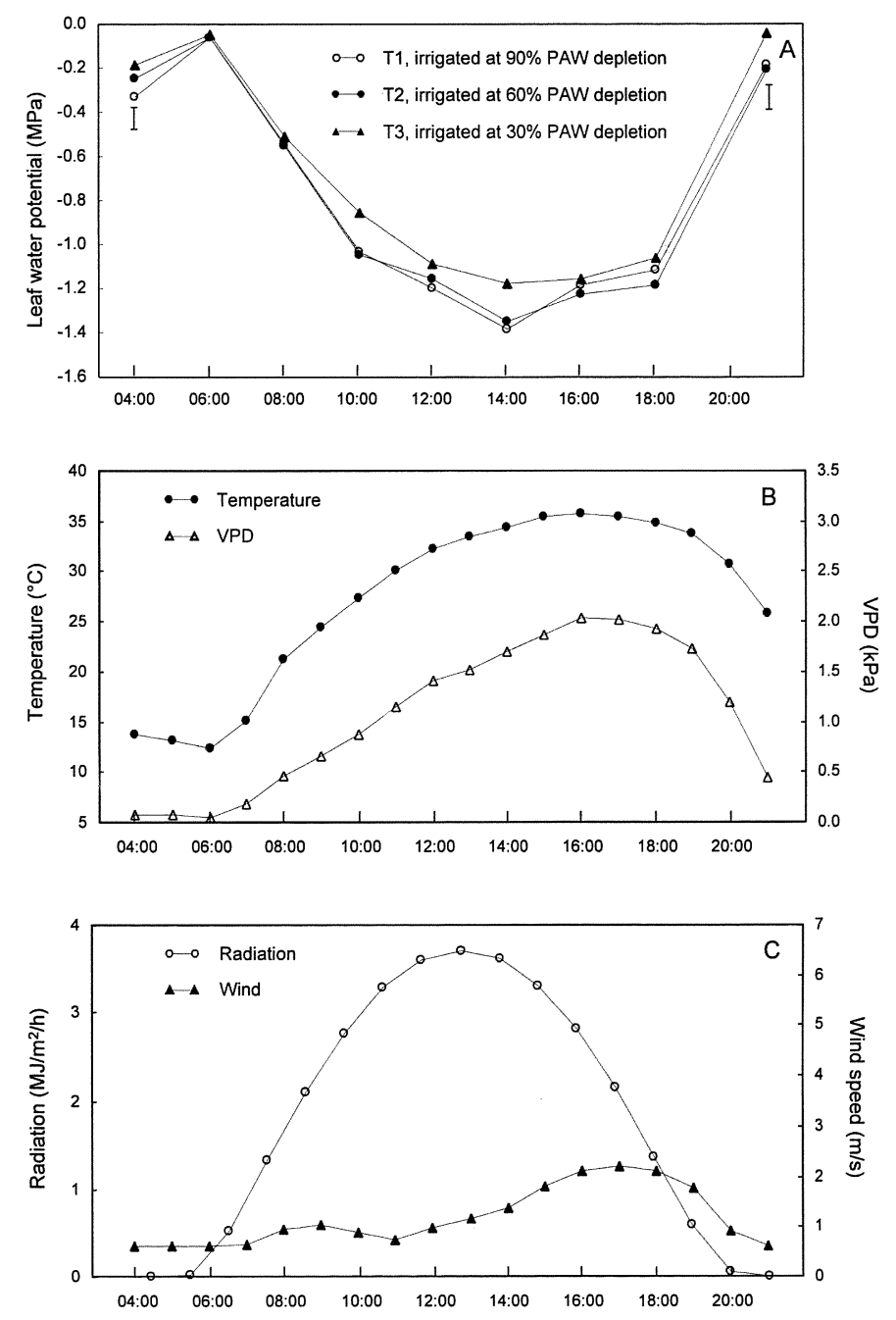

FIGURE 3

Effect of soil water depletion on (A) leaf water potential of Sultanina in relation to (B) temperature and vapour pressure deficit (VPD) as well as (C) radiation and wind speed as measured on 11 January 1996 at Upington. Vertical bars indicate significant differences $(p \leq 0.05)$. 

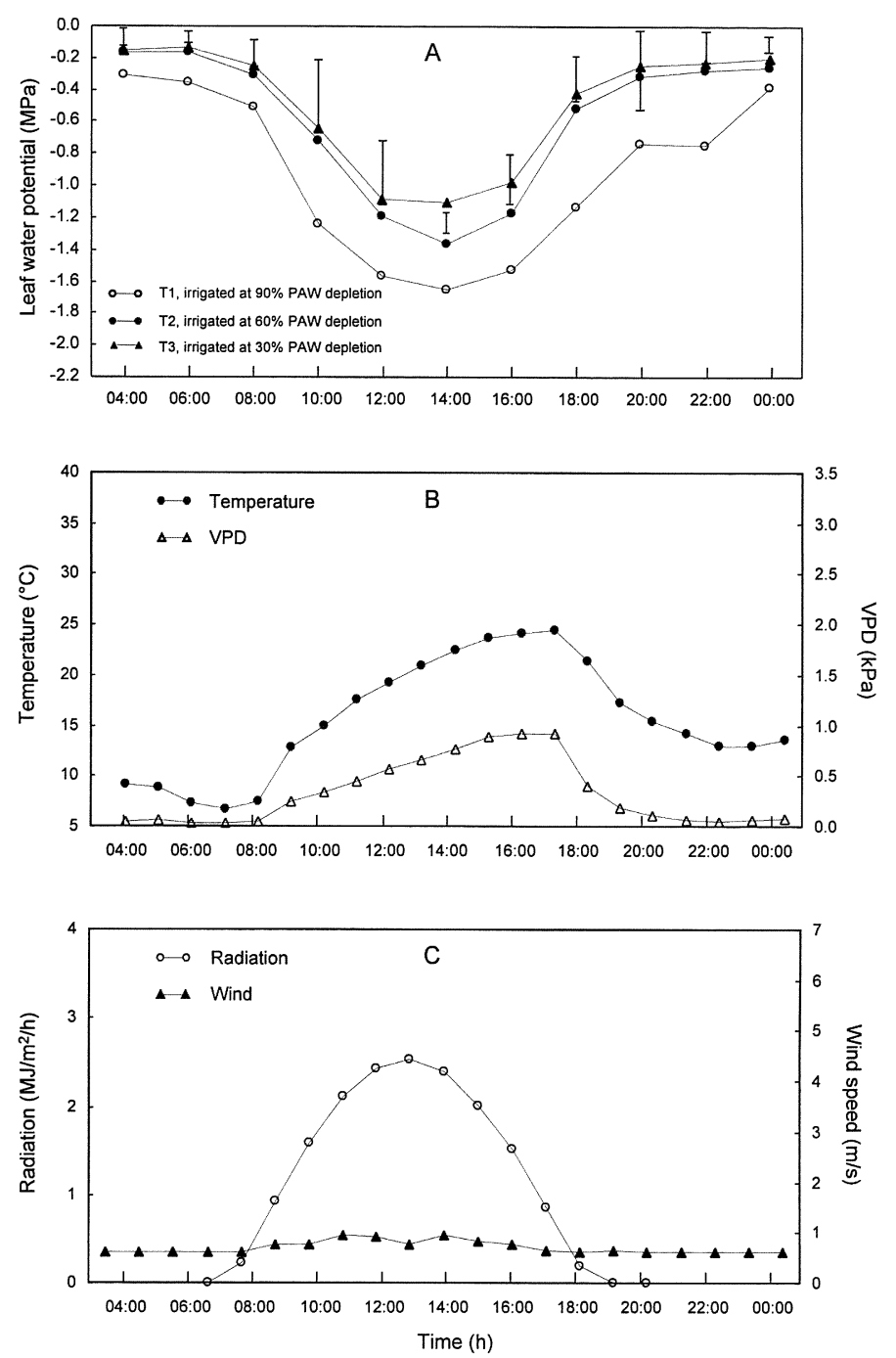

FIGURE 4

Effect of soil water deficits during the post-harvest period on (A) leaf water potential of Sultanina in relation to (B) temperature and vapour pressure deficit (VPD) as well as (C) radiation and wind speed as measured on 7 May 1996 at Upington. Vertical bars indicate significant differences $(p \leq 0.05)$.
Van Zyl (1987) showed that leaf water potential of Colombar grapevines measured at 14:00 correlated better with soil water matric potential than with relative humidity or photosynthetic active radiation. In contrast, leaf water potential measured at 14:00 ( $\left.\Psi_{14}\right)$ was poorly correlated to $\Psi_{\mathrm{m}}$ (Table 3 ). Similar to the pre-dawn situation, variation in $\Psi_{14}$ was best explained when $\Psi_{\mathrm{m}}$ as well as VPD were considered. However, $\Psi_{14}$ decreased with increasing VPD compared to $\Psi_{\mathrm{pd}}$. A decrease in water saturation of the atmosphere during the day will induce partial stomatal closure (Düring, 1987), which in turn will increase leaf water potential. On the other hand, $\Psi_{14}$ tended to increase with decreasing radiation (Table 3 ). A decrease in radiation will also result in partial stomatal closure (Düring, 1976; Düring \& Loveys, 1982) or a reduction in whole plant transpiration as quantified by measuring sap flow (Myburgh, 1998). However, under the conditions of this study, radiation seemed not to make a meaningful contribution in explaining $\Psi_{1}$ variation compared to VPD. Wind speed, which was generally less than $3 \mathrm{~m} / \mathrm{s}$ when diurnal cycles were measured, had no significant effect on the variation in $\Psi_{\text {pd }}$ or $\Psi_{14}$ (data not shown). This is in agreement with the fact that leaf water potential only decreased significantly when grapevines were exposed to exceptionally high wind speeds of $c a 10 \mathrm{~m} / \mathrm{s}$ (Kobriger et al., 1984).

\section{Vegetative growth}

Despite the lack of significant differences in water stress between treatments, vegetative growth responded readily to soil water depletion level. Irrigation at $90 \%$ PAW depletion reduced vegetative growth significantly in comparison to irrigation at $30 \%$ depletion (Table 4). Similar responses of vegetative growth to increased water availability were reported for Sultanina (Williams et al., 1994; Araujo et al., 1995). Although the tendency towards excessive shoot growth of T3 grapevines could reduce bud fertility significantly (Carbonneau \& Casteran, 1979) and increase the occurrence of diseases under unfavourable weather conditions, no such problems were encountered in this study. Despite variations in vegetative growth between seasons, the general effect of soil water depletion level on growth was maintained over seasons. Leaf water potential did not always differ significantly between treatments, but nevertheless showed consistent

\section{TABLE 3}

Coefficients for equations to relate leaf water potential measured at 04:00 (pre-dawn) and 14:00 to soil matric potential ( $\Psi_{\mathrm{m}}$ ), vapour pressure deficit (VPD) and net radiation ( $\mathrm{n}=12$ for all equations).

\begin{tabular}{|c|c|c|c|c|c|c|}
\hline $\begin{array}{l}\text { Time of leaf water } \\
\text { potential measurement }\end{array}$ & Constant & $\begin{array}{c}\Psi_{\mathrm{m}} \\
(-\mathrm{MPa})\end{array}$ & $\begin{array}{r}\text { VPD } \\
(\mathbf{k P a})\end{array}$ & $\begin{array}{c}\text { Net } \\
\text { radiation } \\
\left(\mathbf{M J} / \mathbf{m}^{2} / \mathbf{h}\right)\end{array}$ & $\mathbf{R}^{2}$ & $\begin{array}{l}\text { Std error of } \\
\text { estimation }\end{array}$ \\
\hline 14:00 & $\begin{array}{l}-0.975 \\
-1.361 \\
-1.132\end{array}$ & $\begin{array}{l}6.666^{*} \\
7.841^{*} \\
8.159^{*}\end{array}$ & $\begin{array}{c}- \\
0.216^{*} \\
0.180^{*}\end{array}$ & $\begin{array}{c}- \\
- \\
-0.063\end{array}$ & $\begin{array}{l}0.3522 \\
0.8253 \\
0.8558\end{array}$ & $\begin{array}{l}0.225 \\
0.123 \\
0.119\end{array}$ \\
\hline
\end{tabular}

* Significant $(p \leq 0.05)$. 
trends which suggested that the cumulative effect of water stress is reflected in vegetative growth.

\section{Yield}

Yield showed large seasonal variation (Table 5). Although all treatments were pruned to the same number of canes, exceptionally high yields were obtained during the 1996/97 season in the case of T2 and T3. Irrigation at $90 \%$ PAW depletion reduced yield significantly in comparison to irrigation at $30 \%$ depletion, where grapevines were not subjected to water stress as discussed above. Lower yield in the case of T1 was primarily due to smaller berries (Table 6). The negative effect of $90 \%$ PAW depletion on berry size already occurred in the early stages of development in comparison to T2 and T3 (Fig. 5). Berry size of Colombar (Van Zyl, 1984b), Cabernet franc (Matthews et al., 1987) and Shiraz (McCarthy, 1997) responded similarly to early water deficits. This indicated that, in the present study, cell division was also limited by drier

\section{TABLE 4}

Effect of plant-available water (PAW) depletion on cane mass of Sultanina over four seasons at Upington.

\begin{tabular}{lccccc}
\hline Treatment & \multicolumn{5}{c}{ Cane mass (t/ha) } \\
\cline { 2 - 6 } & $\mathbf{1 9 9 5 / 9 6}$ & $\mathbf{1 9 9 6 / 9 7}$ & $\mathbf{1 9 9 7 / 9 8}$ & $\mathbf{1 9 9 8 / 9 9}$ & Mean \\
\hline T1, 90\% PAW depletion & 1.50 & 1.30 & 1.34 & 0.65 & 1.20 \\
T2, 60\% PAW depletion & 2.01 & 1.78 & 2.10 & 1.28 & 1.79 \\
T3, 30\% PAW depletion & 2.82 & 2.52 & 2.03 & 2.14 & 2.38 \\
\hline LSD $(p \leq 0.05)$ & NS* & 0.82 & 0.84 & 1.33 & 0.74 \\
\hline
\end{tabular}

* NS = Not significant.

\section{TABLE 5}

Effect of plant-available water (PAW) depletion on yield of Sultanina over four seasons at Upington.

\begin{tabular}{lccccc}
\hline Treatment & \multicolumn{5}{c}{ Yield (t/ha) } \\
\cline { 2 - 6 } & $\mathbf{1 9 9 5 / 9 6}$ & $\mathbf{1 9 9 6 / 9 7}$ & $\mathbf{1 9 9 7 / 9 8}$ & $\mathbf{1 9 9 8 / 9 9}$ & Mean \\
\hline T1, 90\% PAW depletion & 24.7 & 38.8 & 18.9 & 22.5 & 26.2 \\
T2, 60\% PAW depletion & 19.3 & 79.8 & 23.9 & 28.9 & 38.0 \\
T3, 30\% PAW depletion & 32.9 & 72.2 & 30.3 & 35.8 & 42.8 \\
\hline LSD $(p \leq 0.05)$ & NS* & 30.0 & 14.2 & NS & 12.6 \\
\hline
\end{tabular}

* NS = Not significant.

\section{TABLE 6}

Effect of plant-available water (PAW) depletion on berry mass of Sultanina over four seasons at Upington.

\begin{tabular}{lccccc}
\hline Treatment & \multicolumn{5}{c}{ Berry mass (g) } \\
\cline { 2 - 6 } & $\mathbf{1 9 9 5 / 9 6}$ & $\mathbf{1 9 9 6 / 9 7}$ & $\mathbf{1 9 9 7 / 9 8}$ & $\mathbf{1 9 9 8 / 9 9}$ & Mean \\
\hline T1, 90\% PAW depletion & 1.35 & 1.07 & 1.21 & 1.49 & 1.28 \\
T2, 60\% PAW depletion & 1.51 & 1.37 & 1.76 & 1.66 & 1.58 \\
T3, 30\% PAW depletion & 1.65 & 1.74 & 1.69 & 1.82 & 1.72 \\
\hline LSD $(p \leq 0.05)$ & 0.27 & 0.38 & 0.43 & NS & 0.21 \\
\hline
\end{tabular}

* NS = Not significant. soil conditions. Irrigation at 30\% PAW depletion did not increase production in comparison to grapevines irrigated at $60 \%$ depletion. This suggests that even under favourable radiation conditions (Table 2), shading of buds by excessive growth (Table 4) might have had a slight negative effect on fertility of grapevines irrigated at $30 \%$ PAW depletion. With the exception of the first season (1995/96), when yield of T1 was higher than that of T2, the effect of soil water depletion on yield was maintained over seasons.

\section{Total soluble solids, total titratable acidity and pH}

Irrigation at $90 \%$ PAW depletion only resulted in significantly higher total soluble solids (TSS) compared to T2 and T3 during the 1996/97 season (Table 7). Since high yields can reduce the rate of sugar accumulation (Smart \& Coombe, 1983 and references therein), the extremely high yields of T2 and T3 (Table 5) probably delayed sugar accumulation during this particular season. In a field trial over six years under more moderate climatic conditions, TSS of Colombar did not respond to different soil water depletion levels (Van Zyl, 1984a). Similarly, deficit irrigation had no effect on TSS of Bukkettraube on a sandy soil (Conradie \& Myburgh, 2000). Hence, results of the present study confirmed the insensitivity of TSS to soil water depletion level and that crop load could have a more meaningful effect on sugar accumulation. In fact, Coombe (1992) showed that Riesling grapevines with a reduced crop load reached a potential harvest date earlier compared to full-cropped ones that were subjected to water deficits. Soil water depletion level had no effect on total titratable acidity or $\mathrm{pH}$ of the juice during any season (data not shown). Mean total titratable acidity and $\mathrm{pH}$ at harvest were 5.4 $\mathrm{g} / \mathrm{L}$ and 3.18, respectively.

\section{Raisin Quality}

Soil water depletion level had no effect on quality grading of dipped raisins (Table 8). The water-stress levels maintained in this study were probably insufficient to induce browning of dipped raisins as reported by Nagarajah (1992). However, quality of sun-dried raisins was reduced by dry soil conditions. In fact, no choice-grade raisins could be produced where grapevines were irrigated at $90 \%$ PAW depletion and only $17.8 \%$ was produced in the case of $60 \%$ depletion. During grading, raisins of T1 and T2 were described according to industry standards as "of poor texture", whereas T3 raisins were "fairly fleshy". There is currently no acceptable explanation for the negative effects of water deficits on the quality of sun-dried raisins, while the quality of dipped raisins was unaffected.

\section{TABLE 7}

Effect of plant-available water (PAW) depletion on total soluble solids in Sultanina juice over three seasons at Upington.

\begin{tabular}{lcccc}
\hline Treatment & \multicolumn{4}{c}{ Total soluble solids $\left({ }^{\circ} \mathbf{B}\right)$} \\
\hline & $\mathbf{1 9 9 5 / 9 6}$ & $\mathbf{1 9 9 6 / 9 7}$ & $\mathbf{1 9 9 7 / 9 8}$ & Mean \\
\hline T1, 90\% PAW depletion & 22.7 & 20.4 & 23.5 & 22.2 \\
T2, 60\% PAW depletion & 23.6 & 18.0 & 24.1 & 21.9 \\
T3, 30\% PAW depletion & 22.2 & 19.2 & 23.9 & 21.8 \\
\hline LSD $(p \leq 0.05)$ & NS* & 1.2 & NS & NS \\
\hline
\end{tabular}

* NS = Not significant. 


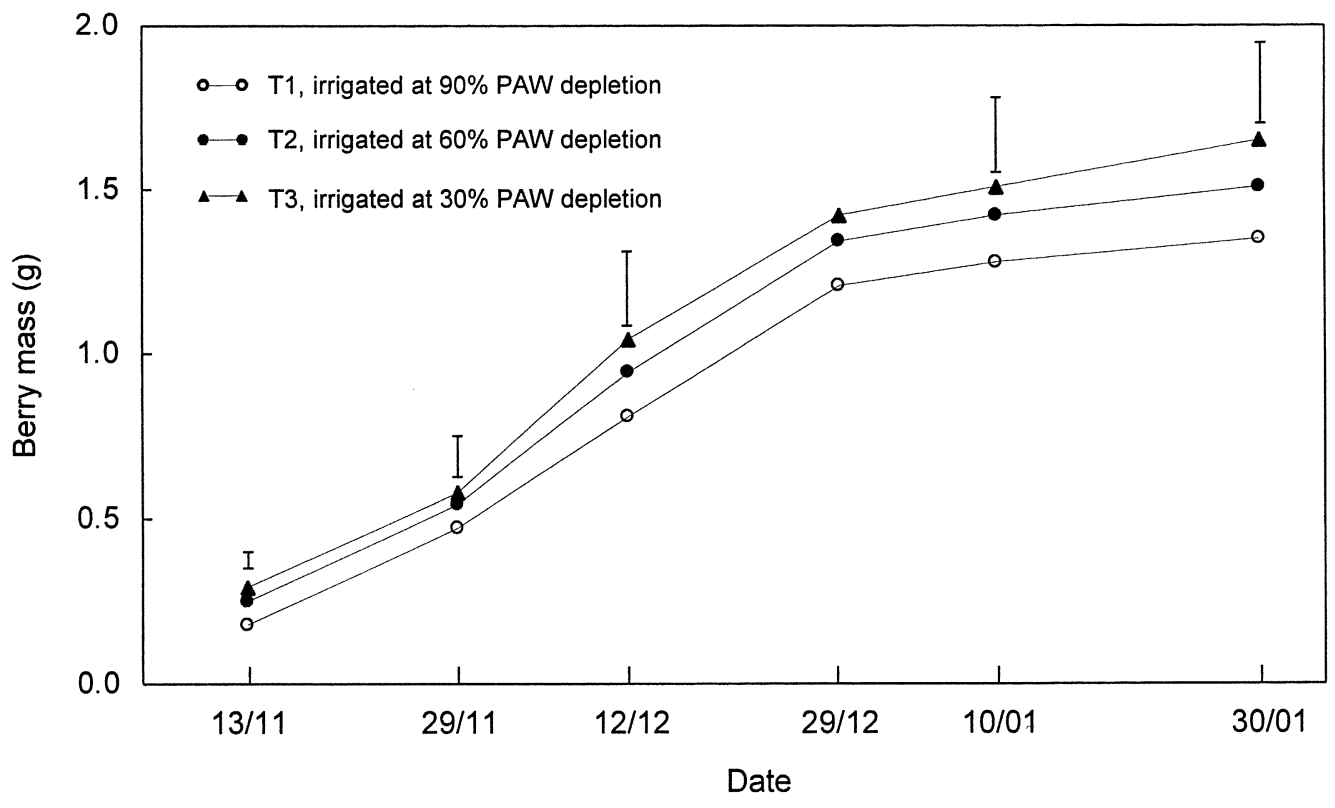

FIGURE 5

Effect of soil water depletion level on berry development of Sultanina as measured during the 1995/96 season at Upington. Vertical bars indicate significant differences $(p \leq 0.05)$.

\section{TABLE 8}

Effect of plant-available water (PAW) depletion on mean Sultanina raisin-quality grading as determined over three seasons at Upington.

\begin{tabular}{|c|c|c|c|c|c|c|}
\hline \multirow[t]{2}{*}{ Treatment } & \multicolumn{3}{|c|}{ Dipped raisins } & \multicolumn{3}{|c|}{ Sun-dried raisins } \\
\hline & $\begin{array}{c}\text { Choice } \\
(\%)\end{array}$ & $\begin{array}{c}\text { Standard } \\
(\%)\end{array}$ & $\begin{array}{c}\text { Sub-std. } \\
(\%)\end{array}$ & $\begin{array}{c}\text { Choice } \\
(\%)\end{array}$ & $\begin{array}{c}\text { Standard } \\
(\%)\end{array}$ & $\begin{array}{c}\text { Sub-std. } \\
(\%)\end{array}$ \\
\hline $\mathrm{T} 2,60 \%$ PAW depletion & 56.6 & 34.4 & 5.0 & 17.8 & 51.0 & 21.9 \\
\hline T3, 30\% PAW depletion & 58.9 & 31.7 & 4.8 & 53.3 & 24.4 & 15.9 \\
\hline $\operatorname{LSD}(p \leq 0.05)$ & NS* & NS & NS & 52.7 & NS & NS \\
\hline
\end{tabular}

* NS = Not significant.

\section{CONCLUSIONS}

Leaf water potential, as a means of assessing plant water status of Sultanina, is not solely a function of soil water availability, but also of meteorological conditions. Under the conditions which prevailed in the present study VPD, in particular had a significant effect on leaf water potential determined pre-dawn as well as at 14:00. In comparison to $30 \%$ and $90 \%$ PAW depletion, the ideal balance between vegetative growth, production and water-use efficiency of Sultanina for dipped raisin production was obtained with irrigation at 60\% PAW depletion. To ensure raisin quality, water deficits should be avoided by irrigation at $30 \%$ PAW depletion if sun-dried raisins are to be produced. Since the more fertile soils could induce excessive growth, these optimum depletion levels may not be applicable for irrigation of Sultanina on heavier, more fertile alluvial soils. This aspect, as well as the causes of the observed negative effects of water deficits on quality of sundried raisins, needs to be addressed by further research.

\section{LITERATURE CITED}

Allen, R.G., Smith, M., Perrier, A. \& Pereira, L.S., 1994. An update for the definition of reference evapotranspiration. ICID Bulletin 43, 1-34.

Allen, R.G., Pereira, L.S., Raes, D. \& Smith, M., 1998. Crop evapotranspiration. Guidelines for computing crop water requirements. FAO Irrigation and Drainage Paper No. 56. FAO, Rome.

Araujo, F., Williams, L.E. \& Matthews, M.A., 1995. A comparative study of young "Thompson Seedless" grapevines (Vitis vinefera L.) under drip and furrow irrigation. II. Growth, water use efficiency and nitrogen partitioning. Sci. Hort. 60 , 251-265.

Buttrose, M.S., 1974. Fruitfulness in grapevines: Effects of water stress. Vitis 12, 299-305.

Choné, X., Van Leeuwen, C., Dubourdieu, D. \& Gaudillère, J.P., 2001. Stem water potential is a sensitive indicator of grapevine water status. Ann. Bot. 87, 477-483.

Carbonneau, A. \& Casteran, P., 1979. Irrigation-depressing effect on floral initiation of Cabernet Sauvignon grapevines in Bordeaux area. Am. J. Enol. Vitic. 30, $3-7$

Christensen, P., 1975. Response of "Thompson Seedless" grapevines to the timing of preharvest irrigation cut-off. Am. J. Enol. Vitic. 26, 188-194. 
Conradie, W.J., Van Zyl, J.L. \& Myburgh, P.A., 1996. Effect of soil preparation depth on nutrient leaching and nutrient uptake by young Vitis vinifera L. cv. Pinot noir. S. Afr. J. Enol. Vitic. 17, 43-52.

Conradie, W.J. \& Myburgh, P.A., 2000. Fertigation of Vitis vinifera L. cv. Bukketttraube/110 Richter on a sandy soil. S. Afr. J. Enol. Vitic. 21, 40-47.

Coombe, B.G., 1992. Research on development and ripening of the grape berry. Am. J. Enol. Vitic. 43, 101-110.

Düring, H., 1976. Untersuchungen zur Umweltabhängigkeit der stomatären Transpiration bei Reben. I. Beleuchtungsstärke und Luftfeuchtigkeit. Vitis 15, 82-87.

Düring, H., 1987. Stomatal responses to alterations of soil and air humidity in grapevines. Vitis $26,9-18$.

Düring, H. \& Loveys, B.R., 1982. Diurnal changes in water relations and abscisic acid in field grown Vitis vinifera cvs. I. Leaf water potential components and leaf conductance under humid temperate and semiarid conditions. Vitis 21, 223-232.

Eastham, J. \& Gray, S., 1998. A prelimenary evaluation of the suitability of sap flow sensors for use in scheduling vineyard irrigation. Am. J. Enol. Vitic. 49, 171176.

English, J.T., Bledsloe, A.M., Marois, J.J. \& Kliewer, W.M., 1990. Influence of grapevine canopy management on evaporative potential in the fruit zone. Am. J. Enol. Vitic. 41, 137-141.

Green, S.R., McNaughton, K.G. \& Clothier, B.E., 1989. Observations of nighttime water use in kiwifruit vines and apple trees. Agric. Forest. Meteorol. 48, 251261 .

Greenspan, M.D., Schultz, H.R. \& Matthews, M.A., 1996. Field evaluation of water transport in grape berries during water deficits. Physiol. Planta. 97, 55-62.

Hardie, W.J. \& Considine, J.A., 1976. Response of grapes to water-deficit stress in particular stages of development. Am. J. Enol. Vitic. 27, 55-61.

Kobriger, J.M., Kliewer, W.M. \& Lagier, S.T., 1984. Effects of wind on water relations of several grapevine cultivars. Am. J. Enol. Vitic., 35, 164-169.

Klute, A., 1986. Water retention: Laboratory methods. In: Klute, A. (ed.). Methods of soil analysis. Part 1, Physical and mineralogical methods. No. 9, Agronomy series. Madison, Wisconson, USA. pp. 635-662.

Matthews, M.A., Anderson, M.M. \& Schultz, H.R., 1987. Phenologic and growth responses to early and late season water deficits in Cabernet franc. Vitis 26, 147-160.

McCarthy, M.G., 1997. The effect of transient water deficit on berry development of cv. Shiraz (Vitis vinifera L.). Aust. J. Grape Wine Res. 3, 102-108.

Myburgh, P.A., 1996. Response of Vitis vinifera L. cv. Barlinka/Ramsey to soil water depletion levels with particular reference to trunk growth parameters. S. Afr. J. Enol. Vitic. 17, 3-14.

Myburgh, P.A., Van Zyl, J.L. \& Conradie, W. J., 1996. Effect of soil depth on growth and water consumption of young Vitis vinifera L cv. Pinot noir. S. Afr. J. Enol. Vitic. 18, 53-62.
Myburgh, P.A., 1998. Water consumption of South African vineyards: A modelling approach based on the quantified combined effects of selected viticultural, soil and meteorological parameters. $\mathrm{PhD}$ dissertation, Stellenbosch University, Private bag X1, 7602 Matieland (Stellenbosch), South Africa.

Myburgh, P.A., 2003. Responses of Vitis vinifera L. cv. Sultanina to water deficits during various pre- and post-harvest phases under semi-arid conditions. S. Afr. J. Enol. Vitic. 24, 25-33.

Nagarajah, S., 1992. Water stress and the colour of dried Sultanas. Dried Fruits News, December, 10-12.

Saayman, D. \& Lambrechts, J.J.N., 1995. The effects of irrigation system and crop load on the vigour of Barlinka table grapes on a sandy soil, Hex River Valley. S. Afr. J. Enol. Vitic. 16, 26-34.

Scholander, P.F., Hammel, H.T., Bradstreet, E.D. \& Hemmingsen, E.A., 1965. Sap flow in vascular plants. Science $148,339-346$.

Schultz, H.R. \& Matthews, M.A., 1988. Vegetative growth distribution during water deficits in Vitis vinefera L.. Aust. J. Plant Physiol. 15, 641-656.

Smart, R.E. \& Coombe, B.G., 1983. Water relations of grapevines. In: Kozlowski T.T. (ed.). Water deficits and plant growth VII. Academic Press, New York. pp 137-196.

Soil Classification Work Group, 1991. Soil classification - A taxonomic system for South Africa. Memoirs on natural resources of South Africa No. 15. Dept. Agric. Developm., Pretoria.

Stevens, R.M. \& Harvey, G., 1996. Soil water depletion rates under large grapevines. Aust. J. Grape Wine Res. 2, 155-162.

Van Leeuwen, C., Choné, X., Trégoat, O. \& Gaudillère, J.P., 2001. The use of physiological indicators to assess vine water uptake and to manage vineyard irrigation. Australian Grapegrower and Winemaker 449, 18-24.

Van Zyl, J.L., 1984a. Interrelationships among soil water regime, irrigation and water stress in the grapevine (Vitis vinifera $\mathrm{L}$.). $\mathrm{PhD}$ dissertation, Stellenbosch University, Private bag X1, 7602 Matieland (Stellenbosch), South Africa.

Van Zyl, J.L., 1984b. Response of Colombar grapevines to irrigation as regards quality aspects and growth. S. Afr. J. Enol. Vitic. 5, 19-28.

Van Zyl, J.L., 1987. Diurnal variation in grapevine water stress as a function of changing soil water status and meteorological conditions. S. Afr. J. Enol. Vitic. 8, $45-52$.

Williams, L.E., Dokoozlian, N.K. \& Wample, R., 1994. Grape. In: Schaffer, B. \& Anderson, P.C. (eds). Handbook of environmental physiology of fruit crops, Vol I, Temperate crops. CRC Press, Boca Raton. pp. 85-133.

Winkler, A.J., 1962. General viticulture. University of California Press, Los Angeles.

Zeeman, A.S., 1981. Oplei. In: Burger, J.D. \& Deist, J. (eds). Wingerdbou in SuidAfrika. Nietvoorbij, Stellenbosch, South Africa. pp. 185-201. 